\title{
Rectal bleeding due to leech bite: a case report
}

\author{
Sülük ısırığına bağlı rektal kanama: Olgu sunumu
}

\author{
Behçet AL, ${ }^{1}$ Mehmet Emin YENEN, ${ }^{2}$ Mustafa ALDEMIR ${ }^{3}$
}

\begin{abstract}
We present herein a case with a four-day history of fresh rectal bleeding due to leech bite. The cause was found to be a leech in the rectum by anoscope. This pathological condition is extremely rare in urban areas. Leech endoparasitism, although rare, may cause serious, even lethal, complications. Suspicion of leech infestation should be kept in mind when faced with intermittent or severe rectal bleeding in humans, and should be investigated surgically as with all other foreign bodies. In the current study, we present a patient who admitted with rectal bleeding due to leech bite. The leech was removed by hand examination (by forceps) without requiring any surgical attempt.
\end{abstract}

Key Words: Anoscope; clamp; forceps; hand evaluation; leeches; rectal bleeding.
Bu yazıda, sülük ısırığına bağlı oluşan dört günlük taze rektal kanamalı olgu sunuldu. Kanamının nedeni anoskopla rektumda olduğu saptanan sülüktü. Bu patolojik durum şehir alanlarında oldukça azdır. Sülük endoparasitizmi az olmasına rağmen, ciddi ve hatta ölümcül komplikasyonlara neden olmaktadır. İnsanlarda aralıklı veya ciddi rektal kanama ile karşılaştığında sülük infestasyon şüphesi akılda tutulmalıdır ve diğer tüm yabancı cisimlerde olduğu gibi cerrahi olarak incelenmelidir. Burada sülük 1sırığına bağlı rektal kanama ile başvuran bir hastayı sunduk. Sülük, herhangi bir cerrahi girişim yapılmaksızın el değerlendirmesi ile (forseps ile) çıkarıldı.

Anahtar Sözcükler: Anaoskop; klemp; forseps; el ile değerlendirme; sülük; rektal kanama.
Leeches are blood-sucking hermaphroditic parasites that vary in color and range in length from a few millimeters to half a meter; they are cylindrical or leaflike in shape, depending on the contraction of their bodies. ${ }^{[1]}$ Leech infestation primarily occurs in tropical areas, such as in Mediterranean countries, Africa and Asia. ${ }^{[2]}$ They have a mouth, tentacles, three jaws, and suckers specially adapted for attaching to and sucking blood from the skin and mucosal surface of mammalian species. ${ }^{[3]}$ However, as an endoparasite, the leech can cause serious, even lethal, complications, though it is rare. When lodged in the rectum, the parasite can simulate the symptoms of gastrointestinal hemorrhage. Leeches are usually taken into the human body while bathing or drinking unfiltered water or while swimming in contaminated water. They localize on the mucosa of the oropharynx, nasopharynx, tonsils, esophagus, or nose, but rarely in the rectal mucosa. ${ }^{[4-7]}$ Leeches are not harmful to humans at all times, and rarely, they are used in replantation and flap survival, especially in the head ${ }^{[8]}$ and also neck regions. ${ }^{[9]}$
We report a case with leech in the rectum who complained of fresh rectal bleeding. We used an easy and innovative method to remove the parasite with a local anesthetic injection while the patient was in the knee-elbow position.

\section{CASE REPORT}

A previously healthy 33-year-old male from a rural community in Batman, southeastern Turkey, presented with a four-day history of fresh rectal bleeding. Two days before the onset of bleeding, he had been aware of anorectal discomfort and a sensation of wanting to defecate. The rectal bleeding was independent from defecation. Twenty-four hours before admission to our Emergency Department, his rectal bleeding increased, and he was evaluated in another medical center for this complaint. His clinical and conventional radiological examination of the chest and gastrointestinal system revealed no pathological finding. He was thus sent to the Emergency Department of Batman State Hospital for further evaluation. On admission, he was pale, his

\footnotetext{
${ }^{1}$ Department of Emergency Medicine, Gaziantep University Faculty of Medicine, Gaziantep; ${ }^{2}$ Department of General Surgery, Batman State Hospital, Batman; ${ }^{3}$ Department of Emergency Medicine, Dicle University Faculty of Medicine, Diyarbakır, Turkey.
}

${ }^{1}$ Gaziantep Üniversitesi Tıp Fakültesi, Acil Tıp Anabilim Dalı, Gaziantep; ${ }^{2}$ Batman Devlet Hastanesi, Genel Cerrahi Kliniği, Batman; ${ }^{3}$ Dicle Üniversitesi Tıp Fakültesi, Acil Tıp Anabilim Dalı, Diyarbakır. 
pulse rate was $87 / \mathrm{min}$, and blood pressure was $110 / 70$ $\mathrm{mmHg}$. The complete blood count revealed a hypochromic microcytic anemia. The results of blood count were as follows: erythrocyte count 3.4 million per $\mathrm{mm}^{3}$ (reference range [r.r.]: 4.2-5.9 million per $\mathrm{cu} \mathrm{mm}^{3}$ ); hematocrit 31\% (r.r.: 39-49\%); hemoglobin $10 \mathrm{~g} / 100 \mathrm{ml}$ (r.r.: $13-18 \mathrm{~g} / 100 \mathrm{ml}$ ); mean corpuscular volume 75 $\mu \mathrm{m}^{3}$ (r.r.: $80-100 \mu \mathrm{m}^{3}$ ); mean corpuscular hemoglobin 24 pg (r.r. $=27-32 \mathrm{pg}$ ); and mean corpuscular hemoglobin concentration 28\% (r.r.: $32-36 \%$ ). The platelet count was $210 \mathrm{~K} / \mu \mathrm{L}$. Total white blood cell count was $5400 / \mu \mathrm{L}$ with $16 \%$ eosinophils. A thick blood film for malaria parasites was negative. The international normalized ratio (INR) and partial thromboplastin time (PTT) were both normal. The remaining examination did not reveal any abnormalities, in particular no obvious bleeding sites, lymphadenopathy or hepatosplenomegaly. In the knee-elbow position, anoscope examination revealed first degree internal hemorrhoid. We found a dark brown, smooth foreign body just above the internal hemorrhoidal swelling. It was a small parasite that proved to be an aquatic leech (family Hirudinidae; order Gnathobdellida; class Hirudinea; phylum Annelida) (Figs. 1, 2). Direct extraction of the worm with forceps failed because of the worm's slippery body surface. Several attempts at spraying $4 \%$ lidocaine solution onto the worm failed to anesthetize it. After we clamped its mouth, and waited for four minutes, it stopped moving and was removed easily from the rectal mucosa with forceps. The worm with a blood-sucker was identified as a leech, which measured about $5.5 \mathrm{~cm}$ in length. It was still alive. After the leech was removed, due to continued oozing of blood from the lesion, compression with a tampon was performed. After a period of 8 hours, the blood oozing stopped. Flexible rectoscopy was performed for other probable parasites, and no other leeches were found.

According to the patient's history, he had swum in a contaminated pool six days previously. The patient recovered promptly and showed no more signs or symptoms of rectal bleeding or anemia. He was discharged one day later. A long-term follow-up was not possible due to the local circumstances.

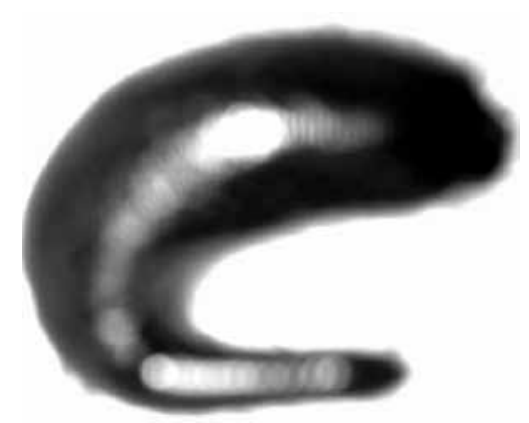

Fig. 1. A lateral view of the leech.

\section{DISCUSSION}

The leech is a blood-sucking worm, belonging to the phylum Annelida, class Hirudinea. ${ }^{[10]}$ Leeches that attack man may be divided into two classes (aquatic and land). Land leeches have powerful jaws that can penetrate the skin so that they can attach anywhere on the external surface of the body. Land leeches are common in Southeast Asia, the Pacific Islands and South America. Aquatic leeches have weak jaws and require soft tissues, such as the mucosa of the upper aerodigestive tractus, to feed on; they have a worldwide distribution. ${ }^{[11]}$ Aquatic types are acquired while bathing or drinking unfiltered water or swimming in contaminated pools. Due to this mode of transmission, almost all cases have been reported from lessdeveloped countries where use of safe water is often a problem, especially in rural areas. ${ }^{[12]}$ Aquatic leeches live exclusively in fresh water. They have been described in sites like the esophagus, ${ }^{[11]}$ mouth/pharynx/ larynx, ${ }^{[12]}$ conjunctiva, ${ }^{[13]}$ nose, ${ }^{[14]}$ trachea/bronchi, ${ }^{[15]}$ vagina, ${ }^{[16]}$ bladder, ${ }^{[17]}$ and rectum. ${ }^{[18]}$ When attached to the mucous membrane, they ingest blood averaging $890 \%$ of their weight. ${ }^{[19]}$ In this regard, aquatic leeches are more dangerous than land leeches because they are more likely to cause severe anemia, which may require blood transfusion. ${ }^{[1]}$ Cundall et al. ${ }^{[20]}$ reported three patients with severe anemia, one of whom died. Our patient had suffered from weakness and anorectal pain for approximately four days, and a hypochromic microcytic anemia had developed, but he did not require blood transfusion.

The most common mode of presentation in leech endoparasitism is nasal infestation. ${ }^{[21]}$ In the stomach, the leech is usually destroyed by gastric acid. ${ }^{[1]}$ Therefore, it has not been described in the lower intestines, although it can pass from outside through the anal sphincter into the rectum. ${ }^{[18]}$ However, the presence of a leech in the rectum has been reported in a limited number of articles. In the last 35 years, there were only two case reports on this issue. ${ }^{[18]}$ When the leech is present in the rectum, patients present with intermittent or severe rectal bleeding, anorectal discom-

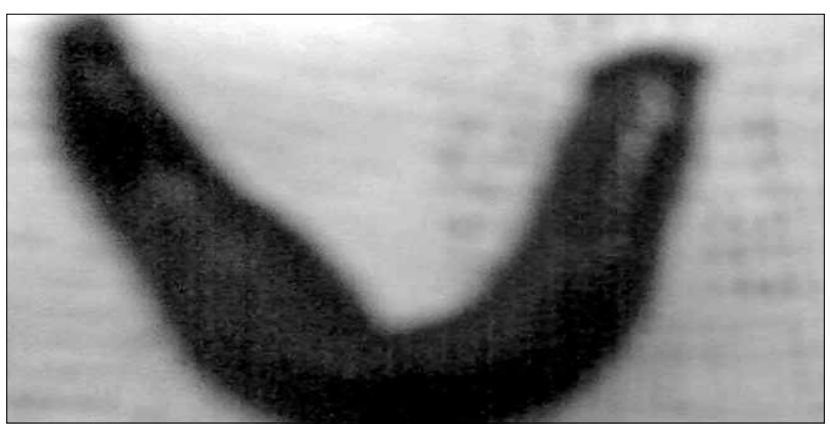

Fig. 2. An anteroposterior view of the leech with the oral opening on the left (length $5.5 \mathrm{~cm}$; diameter $7 \mathrm{~mm}$ ). 
fort, a sensation of wanting to defecate, and sensation of a moving foreign body in the rectum. ${ }^{[18]}$ Cases of leech-induced bleeding from the vagina, bladder and pharynx have been reported but, to the best of our knowledge, this is only the third reported case of rectal bleeding and certainly the first to be managed by anoscope and hand evaluation. In earlier reports, the first from China, the patient was treated conservatively with hemostatic drugs, and bleeding only stopped on the second day after the diagnosis was made. In the second case, from Malaysia, the patient was managed endoscopically, and electrocoagulation was applied to stop the bleeding. ${ }^{[22]}$ The possibility of leech endoparasitism should not be overlooked in patients (especially in children) presenting with epistaxis, rectal bleeding or hemoptysis, and a history of recent contact with fresh water lakes or streams in areas where aquatic leeches are commonly found. ${ }^{[18,19,21]}$ Diagnosis is easy when the leech is in the rectum. However, when lodged in the anorectal mucosa, an examination without general anesthesia may be required. In this location, the differential diagnosis should necessarily include other anorectal or colorectal lesions, such as hemorrhoids, anorectal polyp, malignant tumors, and angiodysplasia. ${ }^{[23,24]}$

Leech bites are painless and result in a triradiate wound that remains open for a long time and heals slowly. ${ }^{[25]}$ As was seen in our case, the commonest complication of leech application is oozing. The amount and duration of bleeding vary according to the area bitten, with bleeding from the vagina, rectum, urinary bladder, and pharynx having been reported. ${ }^{[18,25]}$ Faust et al. ${ }^{[24]}$ reported that prolonged hemorrhage might result in anemia and death. The mean duration of bleeding from a leech bite wound was reported as 10 hours in one study (range: 6.5-23). In our patient, the bleeding continued for six hours and persisted intermittently for the next two hours, in spite of application of a compression tampon. However, he did not have any hematological problems. After the leech was removed, the amount of oozing blood was not excessive, so no other method (hemostatic drugs, electrocoagulation, etc.) was needed to stop it completely. Compression with a tampon was sufficient to control the oozing in this case.

Since a leech attaches strongly with its suckers and has a soft and slippery body surface that ruptures easily, it is difficult to hold and remove a leech with force. ${ }^{[26]}$ If the leech is attached too tightly to the mucosa and resists mechanical removal, then hypertonic sodium chloride solution (more suitable in older children) or cocaine/lidocaine can be applied, which releases the hold of the leech or paralyses it, respectively. Afterwards, it can be removed easily. In our case, we removed the leech mechanically (with clamp and forceps) after it was paralyzed with lidocaine. Then, flexible rectoscopy was performed to search for other parasites, but no other leeches were found.

In summary, rectal bleeding seems to be an uncommon complication of leech bite that can be managed with simple examination such as by inspection, anoscope or hand evaluation. The case should be considered as an emergency, and all precautions should be taken to avoid more bleeding. To prevent this type of disease, people have to be taught more effectively about the necessity to use clean, safe water, and local and government officials must support health education and facilitate access to safe water. Leech infestation should be kept in mind when faced with intermittent or severe rectal bleeding in patients who recount a recent history of swimming in possibly contaminated waters.

\section{REFERENCES}

1. el-Awad ME, Patil K. Haematemesis due to leech infestation. Ann Trop Paediatr 1990;10:61-2.

2. Uygur K, Yasan H, Yavuz L, Dogru H. Removal of a laryngeal leech: A safe and effective method. Am J Otolaryngol 2003;24:338-40.

3. Eldor A, Orevi M, Rigbi M. The role of the leech in medical therapeutics. Blood Rev 1996;10:201-9.

4. Bilgen C, Karci B, Uluöz U. A nasopharyngeal mass: leech in the nasopharynx. Int J Pediatr Otorhinolaryngol 2002;64:736.

5. Kaygusuz I, Yalçin S, Keleş E. Leeches in the larynx. Eur Arch Otorhinolaryngol 2001;258:455-7.

6. Mohammad Y, Rostum M, Dubaybo BA. Laryngeal hirudiniasis: an unusual cause of airway obstruction and hemoptysis. Pediatr Pulmonol 2002;33:224-6.

7. Güloğlu C, Al B, Özhasenekler A, Güllü N, Aldemir M. Üst solunum yolu obstrüksiyonu, burun kanaması ve kronik aneminin nadir bir sebebi olarak sülük: iki olguluk deneyimimiz. Tıp Araştırmaları Dergisi (In Turkish) 2004;2:45-8.

8. García AC, Martín AM, De Luna Gijón CA, Martín Anaya AS, Mondéjar AR. Leech in the epiglottis: an unusual discovery in our times. Am J Otolaryngol 2002;23:91-2.

9. Irish JC, Gullane PJ, Mulholland S, Neligan PC. Medicinal leech in head and neck reconstruction. J Otolaryngol 2000;29:327-32.

10. Labadi MH, Jamal MN. Leeches in the larynx. J Laryngol Otol 1997;111:980-1.

11. White GB. Leeches and leech infestation. In: Cook GC, editor. Manson's tropical diseases. 20th ed. London: Saunders; 1998. p. 1523-5.

12. Solomon E. Leech-an unusual cause of (laryngo-tracheal) obstruction. Ethiop Med J 1991;29:141-2.

13. Alcelik T, Cekic O, Totan Y. Ocular leech infestation in a child. Am J Ophthalmol 1997;124:110-2.

14. Campbell JR, Hart FL, Purnomo. Nasal leech infestation of man. Trop Geogr Med 1987;39:94-5.

15. Ahmadizadeh A. Leech infestation as a potential cause of hemoptysis in childhood. Arch Otolaryngol Head Neck Surg 2002;128:92.

16. Lepage P, Serufilira A, Bossuyt M. Severe anaemia due to leech in the vagina. Ann Trop Paediatr 1981;1:189-90. 
17. Deka PM, Rajeev TP. Unusual cause of hematuria. Urol Int 2001;66:41-2.

18. Raj SM, Radzi M, Tee MH. Severe rectal bleeding due to leech bite. Am J Gastroenterol 2000;95:1607.

19. al-Hadrani A, Debry C, Faucon F, Fingerhut A. Hoarseness due to leech ingestion. J Laryngol Otol 2000;114:145-6.

20. Cundall DB, Whitehead SM, Hechtel FO. Severe anaemia and death due to the pharyngeal leech Myxobdella africana. Trans R Soc Trop Med Hyg 1986;80:940-4.

21. Bergua A, Vizmanos F, Monzón FJ, Blasco RM. Unavoidable epistaxis in the nasal infestation of leeches. Acta Otorrinolaringol Esp 1993;44:391-3. [Abstract]
22.Ji-Tuan X. Four misdiagnosed cases of visceral bleeding caused by Haemadipha japonica. Southeast Asian J Trop Med Public Health 1997;28:673-4.

23. Adams SL. The emergency management of a medicinal leech bite. Ann Emerg Med 1989;18:316-9.

24. Faust EC, Russel PF, Jurg RC. Craig and Faust's clinical parasitology. 8th ed. Philadelphia: Lea \& Febiger; 1970. p. 563-70.

25. Pandey CK, Sharma R, Baronia A, Agarwal A, Singh N. An unusual cause of respiratory distress: live leech in the larynx. Anesth Analg 2000;90:1227-8.

26. Litch JA, Bishop RA. Saturated aqueous sodium chloride solution for the removal of leeches. Trop Doct 2000;30:102. 